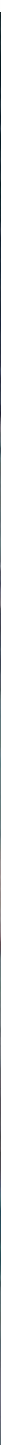

La Puebla de Guzmán evocada a través de la pintura de Sebastián García 1950. Foto: Aniceto Delgado Méndez, IAPH 


\section{Paisajes de dehesas}

Elodia Hernández León y Victoria

Quintero Morón, Universidad Pablo

de Olavide
Entre la objetividad y la subjetividad, entre lo material y lo inmaterial, entre lo que es y lo que se percibe, se mueven las diferentes posiciones que dan respuesta a la pregunta de qué es el paisaje. Son mayoritarias las referencias que destacan la importancia de la mirada, de un paisaje ahora concebido no como un mero lugar físico, sino el conjunto de una serie de ideas, sensaciones y sentimientos que elaboramos a partir del lugar y sus elementos constituyentes (MADERUELO, 2006: 38). Esta definición, centrada en la mirada, nos plantea un reto a la hora de abordar el paisaje como patrimonio y por tanto de dar respuesta al cómo tutelarlo, gestionarlo y en definitiva protegerlo. En la praxis la dificultad se amplia, radicándose en tomar en sus justos términos la declaración de intenciones que encierran las sugerentes construcciones del concepto. Ya que si en algunas definiciones aún continúan omnipresentes los elementos objetivos, curiosamente identificados con "los naturales" -en su acepción más física-, aún más presentes están en las propuestas de intervención sobre los paisajes, a veces bajo la excusa de operatividad. Sin embargo, nos enfrentamos ahora a un paisaje, las dehesas del Andévalo, idóneo para demostrar cuánto de cultural tienen los paisajes. Digamos, un paisaje cultural sin discusión, en el que los elementos culturales no sólo penden de la subjetividad de la mirada sino que serian incluso "tangibles", aislables (si eso pretendiéramos -que no es el caso-), tan objetivos como otros elementos "naturales" que lo componen.

Una de las imágenes paisajisticas más frecuentes en la descripción e identificación del territorio del Andévalo es la dehesa. Un tipo de aprovechamiento que, no obstante, tiene una desigual distribución a lo largo y ancho de la comarca. En general, las tierras más meridionales, más aptas para el cultivo, han sido orientadas al uso cerealístico, perdiendo progresivamente el arbolado. Las zonas de mayor pendiente se han ido desforestando por la búsqueda de recursos madereros, abundando hoy el monte bajo. También las áreas con mayor riqueza pirítica han sido explotadas a lo largo de la historia para la extracción de minerales, construyéndose territorios de gran impronta visual e identitaria. Más recientemente, el retroceso del encinar y alcor- nocal se relaciona con la instalación de industrias madereras y papeleras, produciéndose desde los años sesenta la repoblación de grandes extensiones de eucaliptos. El paisaje del Andévalo es, pues, diverso, lleno de contrastes, protagonizado por la escasez de agua, por su dureza, o en palabras de Pascual Madoz, como una tierra montuosa y agria (1999: 51).

A pesar de la heterogeneidad de usos del suelo, la dehesa si-

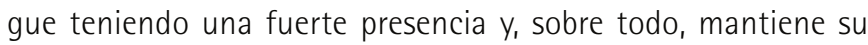
potencialidad como emblema y como uno de los paisajes paradigmáticos de la zona. Un paisaje tantas veces valorado por sus cualidades y riquezas ecológicas pero que es ejemplar en cuanto a cómo el hombre modela su entorno hasta convertir la naturaleza en recurso. La presencia de la dehesa en El Andévalo es, sin duda, resultado de un proceso histórico. Como en otras zonas peninsulares, el uso de terrenos fue objeto de litigios entre agricultores y ganaderos, decantándose la balanza a favor de los principales "labradores" dedicados a la cría de ganado (NÚÑEZ ROLDÁN, 1988). Por ejemplo, en el siglo XVIII se nos muestra el afán de los cabildos locales por proteger el encinar, demandando la intervención de la autoridad señorial: la costumbre indiscriminada de todos los vecinos de hacer sementeras en dicho Campo [Común] mediante rozas, está esquilmando el monte y el arbolado de encinas y chaparros (...) con gran perjuicio del ganado de cerda (Petición al Duque de Medina Sidonia de los Síndicos Procuradores del Campo Común del Andévalo, 1770). Los procesos desamortizadores y la especialización productiva de los campos andaluces pusieron fin a estos vaivenes, consolidando un modelo adehesado y ganadero que permaneció con pocas variaciones hasta mediados del siglo XX.

No puede entenderse la centralidad de la dehesa como imagen de la zona sin relacionarla con dos elementos fundamentales: el fruto de la bellota y el ganado de cerda. Las dehesas se definen por su multiplicidad de usos, se designan como un sistema agrosilvo-pastoril, donde se compaginan diversos aprovechamientos. De hecho, las fincas de encinar de la zona han combinado los usos agrícolas con otros aprovechamientos forestales y han 


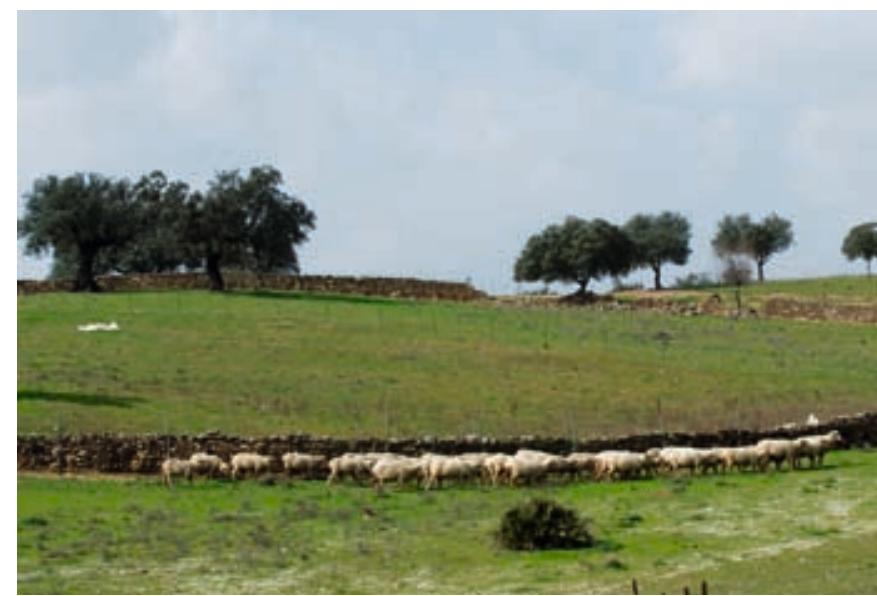

Camino de Cabezas Rubias. Foto: Juan Carlos Cazalla, IAPH

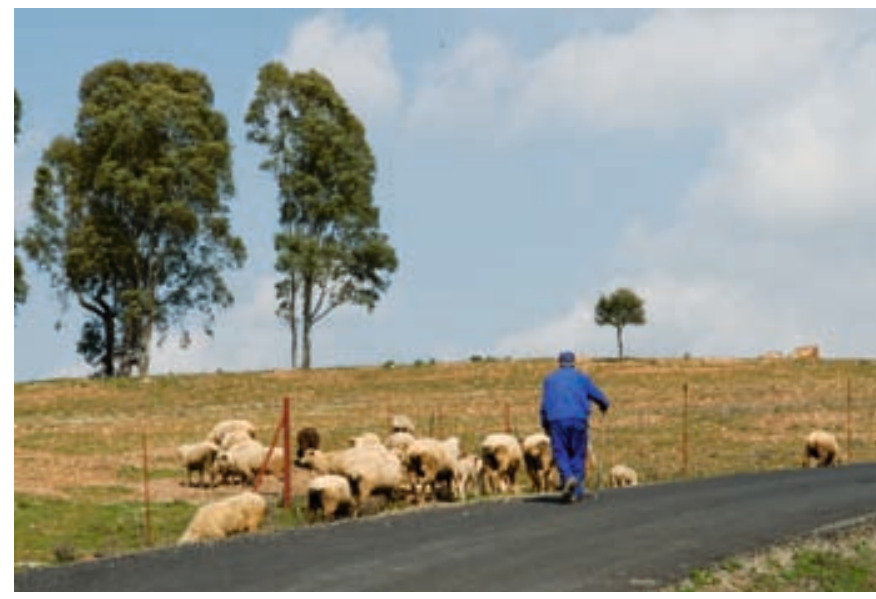

Montes de San Benito (Cerro de Andévalo). Foto: Juan Carlos Cazalla, IAPH

mantenido tradicionalmente -y siguen haciéndolo hoy- una diversidad de ganados que garantizaban el aprovechamiento óptimo de diversos micro-ecosistemas a lo largo del ciclo anual. Sin embargo, el ganado de cerda ha tenido un protagonismo excepcional en esta comarca y se crea una fuerte asociación entre dehesa, encina, bellota y cerdo. En una zona fronteriza y caracterizada por su marginalidad económica, los productos derivados del cerdo han sido históricamente exportados más allá de los límites de la región. Todavía se narra en la zona cómo los arrieros andevaleños transportaban tocinos, chacinas y jamones a los puertos desde los que se zarpaba hacia el Nuevo Mundo. También se recuerdan aún algunas piaras concejiles y muchas personas describen el ciclo de alimentación tradicional del cerdo y sus traslados por distintas zonas de pastos, sembrados o encinares. Estos hitos de la memoria social andevaleña vienen a reflejar el carácter transversal, socialmente hablando, del cerdo y de una de sus fuentes de alimentación principales, la bellota. Este ganado ha sido uno de los más rentables para los grandes propietarios que, a partir del siglo XIX, irán especializándose en piaras cada vez más grandes engordadas en montanera -con los pastos y bellotas de la dehesa- (CÁCERES et ál., 2001; QUINTERO, 2001). Pero además, ha sido tradicionalmente un recurso alimentario también para los pequeños propietarios de tierras y pegujaleros, que alimentaban a sus cochinos en las "hesillas"

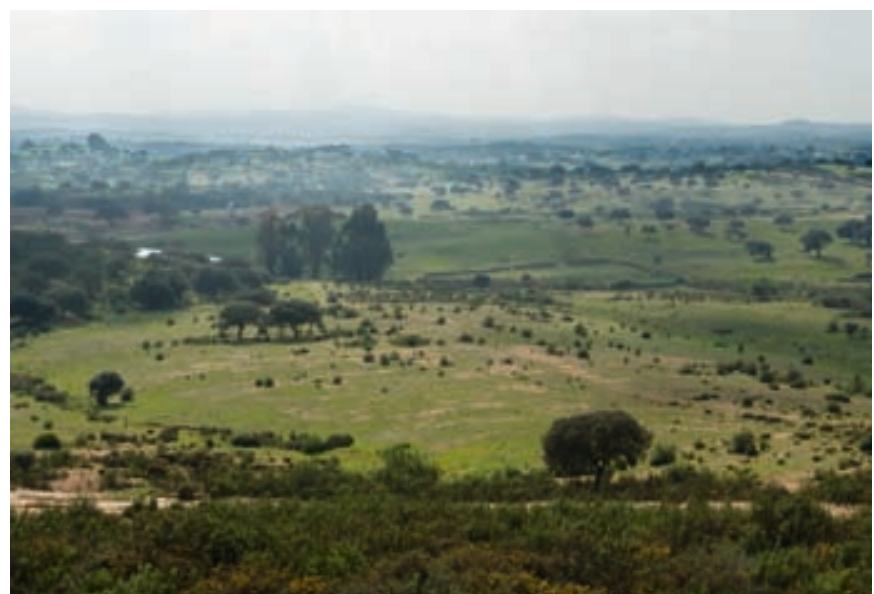

Montes de San Benito (Cerro de Andévalo). Foto: Juan Carlos Cazalla, IAPH

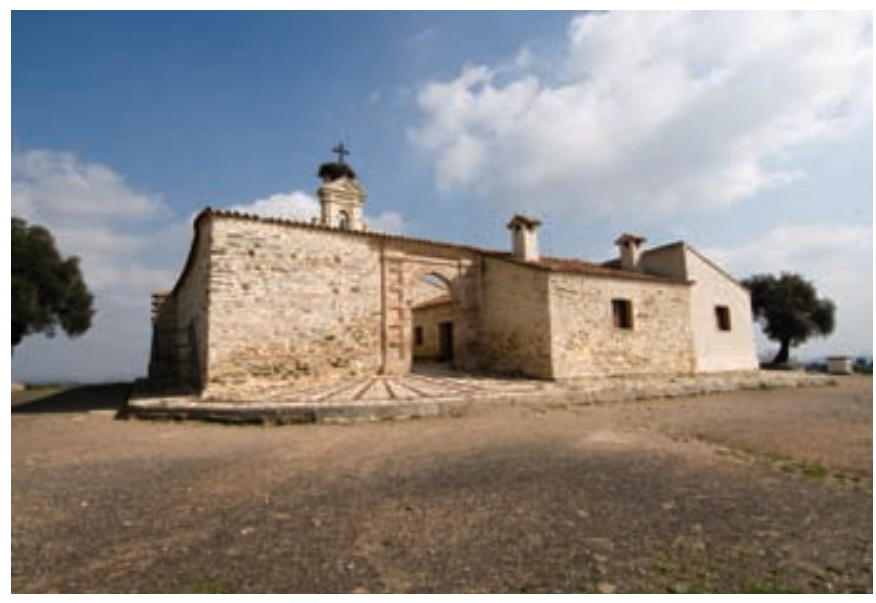

Santuario de San Benito (Cerro de Andévalo). Foto: Juan Carlos Cazalla, IAPH

El uso de terrenos fue objeto de litigios entre agricultores y ganaderos, decantándose la balanza a favor de los principales "labradores" dedicados a la cría de ganado

-pagos cercanos al pueblo de pequeñas dimensiones, pero con algunas encinas- o trayendo bellotas a menudo obtenidas en los "rebuscos". La potencia de la dehesa como imagen de la comarca está pues en relación con las memorias de trabajos, de recorridos, de rituales, en definitiva, de vida.

El paisaje se lee, se interpreta, se narra: si, por una parte, la mina a cielo abierto contrasta con el verde de matorrales y arbolado; por otro lado, los motes de eucaliptos -o "calistros"- suponen el reverso de las lomas adehesadas -las "hesas" o "hesillas"-. En éstas se trabaja para el propietario o en la propia finca familiar, en tareas que se incardinan en la memoria colectiva de la zona: manejos de ganado, siembra para pastos, descorche, recolecciones forestales... Son los procesos de construcción de estas imágenes, a partir de los diferentes usos y apropiaciones del 


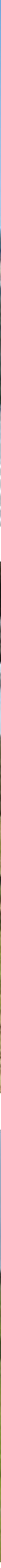

1. Cantera (Calañas). Foto: Juan Carlos Cazalla, IAPH

2-3. Camino hacia el Cerro de Andévalo. Fotos: Juan Carlos Cazalla, IAPH 


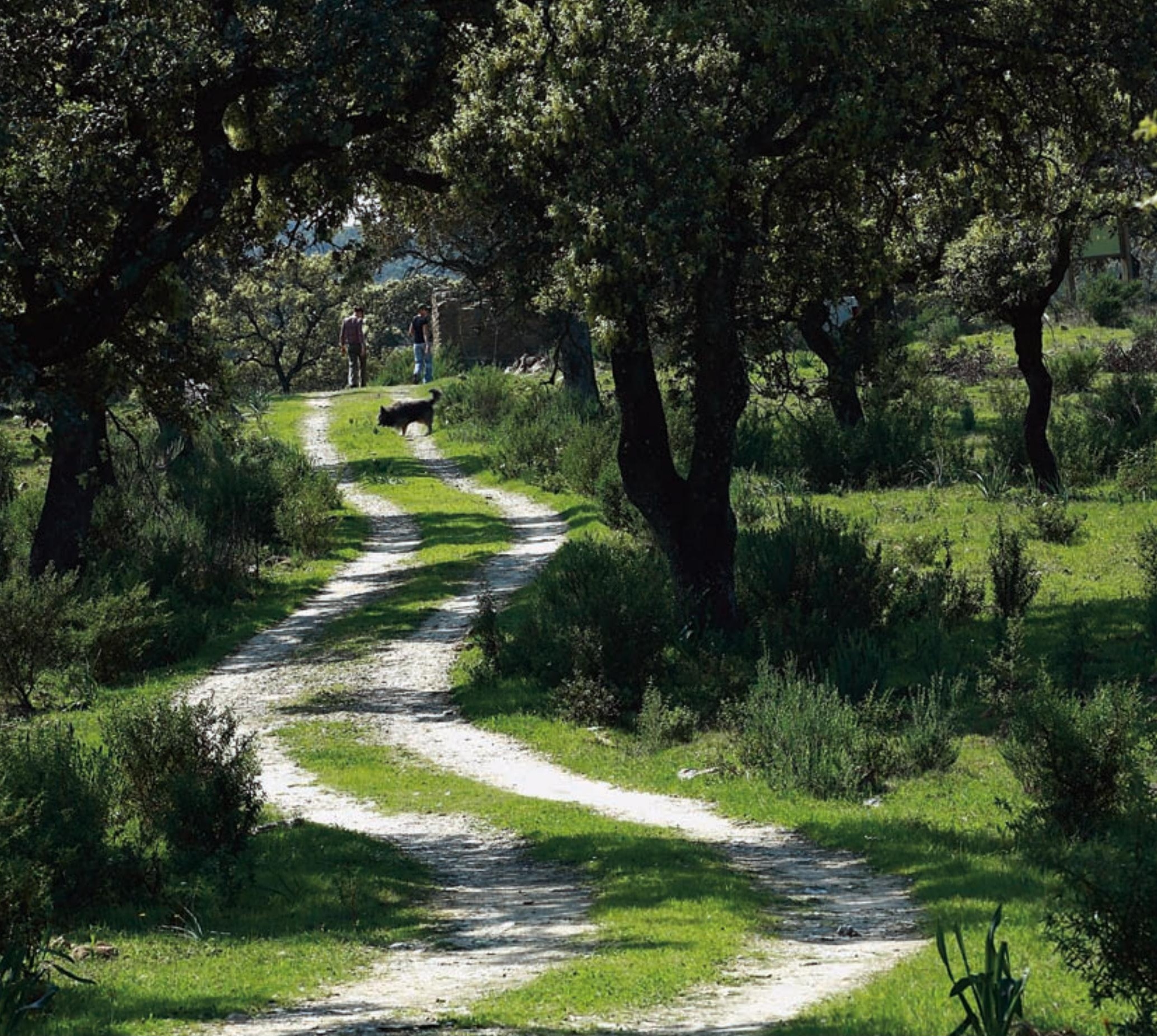

Dehesa del Andévalo. Foto: Miguel Ángel Blanco de la Rubia

territorio, una de las principales riquezas patrimoniales que este territorio encierra. No hay encina, bellota, ni pasto, ni ganado sin manejo. Centrarnos en las actividades que dieron lugar a unos elementos que ahora son interpretados como paisajes de interés patrimonial supone indagar en las percepciones locales derivadas del uso y disfrute del lugar, atender a cómo el paisaje es percibido desde el territorio, a cómo es modelado, interpretado y evocado. Unas interpretaciones que son complejas y no siempre coincidentes puesto que diferentes experiencias y valores sociales pueden dar lugar a lecturas contrapuestas. En la mirada paisajistica confluyen, a veces de forma interpenetrada, a veces ignorándose mutuamente, lecturas de ese territorio hechas por instituciones, por artistas, por turistas, por locales... creándose un conjunto de imágenes estandarizadas. Por supuesto, en el proceso de selección de las imágenes definidoras de un espacio entran en juego los contrastes con los otros paisajes. La dehesa singulariza al An- dévalo frente a la Tierra Llana definida como tierra de campiña o en contraste con la singularidad de los paisajes modelados por las actividades extractivas de la Cuenca Minera. Una parte de las imágenes estandarizadas servirán para definir un territorio sólo al que viene de fuera, al que usa un acercamiento panorámico, con perspectiva. Otra parte podrá ser incorporada a la lectura del espacio desde dentro, la que hace el que siembra, el que tala, el que descorcha, el que "apaña" bellotas o traslada a los "guarros". Ese conjunto de percepciones y matices están presentes en las dehesas del Andévalo: la mirada del ecologista, del pintor, del literato, de las promotoras turísticas, del cazador, del pequeño propietario, del ganadero, del jornalero, del albañil que cría un guarro... Es la confluencia de diferentes miradas la que revalida su importancia patrimonial, son las distintas narraciones las que "educan nuestra atención" permitiendo, a unos y otros, encontrar "sentido" en el paisaje de dehesa andevaleño. 